\title{
PROBLEMS RELATED TO THE ABOLITION OF DIVIDED REAL ESTATE OWNERSHIP
}

\author{
Jolanta Dinsberga ${ }^{1}$, Ilona Tiesniece ${ }^{2}$ \\ ${ }^{1}$ University College of Economics and Culture, Latvia, dinsbija@gmail.com \\ ${ }^{2}$ University College of Economics and Culture, Latvia, itiesniece@yahoo.com
}

\begin{abstract}
Legal relationship between apartment owners in residential buildings and the land owners, that is, divided real estate ownership, was created in the Republic of Latvia in 1990, within the framework of the Land Reform, restoring property rights of the former owners or their heirs or privatising apartments in multi-apartment residential buildings. The existence of such legal relationship created different lease problems and restrictions on the property rights to the owners of both the building and the land. To abolish the legal relationship related to divided real estate ownership, the Ministry of Justice of the Republic of Latvia has developed a draft law Regarding the Abolition of Mandatory Divided Real Estate Ownership in Multi-Apartment Buildings (hereinafter referred to as Draft Law). Unfortunately, in the opinion of authors of this article, there are serious shortcomings to the Draft Law which must be corrected. The aim of the research is to identify the problematic issues by selecting and analysing the legislation on the abolition of the divided real estate ownership, which is related to the calculation of redemption price, payment method and consequences of non-payment, which are not regulated by the new Draft Law. The article reflects research on the determination and calculation of redemption price reglamented by the Draft Law and also analyses the Law of December 8, 1938, On the Abolition of Divided Real Estate Ownership and its practical implementation, which may significantly influence the redemption price and the method of its calculation; however, the mentioned law has been disregarded in developing the Draft Law. Thus the research has both theoretical and practical significance. For the research purposes general research methods, such as historical, analytical, inductive, deductive, logical-constructive and descriptive methods, are used. For the interpretation of legislation norms, grammatical, systemic, teleological and historical methods are used.
\end{abstract}

Keywords: divided real estate ownership; apartment owners; Land Reform

Type of the paper: Theoretical paper

JEL Classification: P37, K11

\section{Introduction}

During the Land Reform, which was started in 1990, legal form of divided real estate was established amongst the apartment owners in multi-apartment residential buildings and the former owners of the land and their heirs, which caused discomfort of ethical and legal character. Because of that, Ministry of Justice of the Republic of Latvia created regulations for the abolition of divided real estate ownership. Ministry of Justice of the Republic of Latvia has elaborated the government draft law Regarding the Abolition of Mandatory Divided Real Estate Ownership in Multi-Apartment Buildings (hereinafter referred to as Draft Law). However, the Draft Law has been repeatedly criticised, and several essential issues have not been duly reglamented in it.

The goal of the research is to select and analyse the legislation, case law and opinion of the field experts on the abolition of the divided real estate ownership with an intention to identify topical issues that are not regulated by the Draft Law and offer possible solutions related to the calculation of redemption price, payment method and consequences of non-payment.

The questions for the research are the following: (1) what legal and practical problems are not addressed in the new Draft Law for the remediation of the divided real estate ownership issue? (2) 
how to elaborate the Draft Law, to ensure optimal solution for the problem of divided real estate ownership in Latvia?

Research hypothesis: in order to ensure the equality and fairness amongst all former owners or their heirs after the restoration of land ownership under multi-apartment residential buildings, in calculating the redemption price, it is necessary to take into account the enforcement of the law of December 8, 1938, On the Abolition of Divided Real Estate Ownership in relation to the fulfilment or nonfulfilment of the one-off redemption payment.

The research shows that the issue of apartment owner solvency has not been taken into account in developing the Draft Law and the method of redemption price calculation as well as the term and consequences of procedure defined by the Draft Law have not been properly assessed and justified. Also the law of December 8, 1938, On the Abolition of Divided Real Estate Ownership has been neglected. The mentioned law provided that upon the abolition of divided real estate ownership, the users who are given full ownership rights as a result of the given law shall pay one-off redemption payment to the general owner. However, a part of the citizens ignored the given law and did not pay the redemption price.

In the beginning of the Land Reform, the former legal owners and their heirs had the right to restore their previous status even though the redemption price had not been paid. In the authors' view, this is a violation of the principles of equality and justice, as in equal real circumstances, one category of citizens was in a more advantageous position than the other. As a result of it, there is an absurd situation - those former owners or their heirs who did not pay one-off redemption price restored their ownership and actually received the parcel as a gift. Today, in addition, these citizens can receive lease payment and the redemption payment - it is a threefold benefit that cannot be justified. Therefore, the authors of the research will address the issue of redemption price calculation, payment procedure and consequences of non-payment, taking into account the historical aspects, although there are several other drawbacks to this Draft Law. It must be added that the problem of divided real estate ownership existed in other European countries. However, assessing the existing research results and the adoption and historical aspects of legislation in Latvia, the authors decided that detailed analysis of experience in other states will not contribute to this research, as it has been decided that it would be reasonable to make the necessary corrections in the developed Draft Law, which stem from the historical aspects of Latvian legislation and the present social and political situation in Latvia.

\section{Literature Review}

There has been wide discussion amongst the experts of civil justice field in relation to the research on the issue of the abolition of the divided real estate ownership in both Latvia and other states of Europe, where this problem has been important. It must be added that these discussions basically are available on the Internet. There are few scientific publications that would address this issue.

In authors' opinion, a thorough research on the request of the Ministry of Justice has been performed by business law firm Sorainen - 'On the Legal Framework of Real Estate Ownership After the Completion of the Land Reform - the Problem of Full Implementation of Civil Law Concept of Land and Building Indivisibility' (Ministry of Justice, 2008).

The study discusses in detail the issue of divided real estate, analyses the relevant legislation, examines the experience of other countries and offers possible solutions. It points out that it would be advisable to enclose the issues related to this new legislation in a separate law (the so-called 'umbrella law'). This law could consolidate the legislation regulating the completion of the Land Reform, and it would determine the main principles. In relation to the plausible redemption price, it indicates that the price should be economically justifiable (market price). In this context, it would be advisable to consider the assessment of the whole real estate (land parcel and buildings) and then the value of the land parcel separately, assuming that there is no building on it owned by another person (Ministry of Justice, 2008). 
Analytical research has been carried out several times by the State Land Service. For example, in the study 'Divided real estate and forced lease in Riga multi-apartment residential buildings', it has been concluded that ' $[\ldots]$ in present circumstances the land under multi-apartment residential buildings is attractive to investment' (State Land Service, 2012).

In the study on the necessity to modernise the Civil Law part of Property Law (fourth, fifth, sixth and seventh subchapters), it is pointed out: '[...] it is necessary to introduce new institutions that could substitute the effective system of the divided real estate ownership. Such institutes exist in the legislation of other post-Soviet countries. To this end, it would be advisable to supplement the part on other property rights with a subsection on the ownership of a building (superficies) and emphyteusis, as well as trust rights, taking as an example the legislation of property rights in Estonia and Lithuania. If the conceptual approach is clear, it would relatively easy to develop and incorporate these norms, taking into account that in Estonia and Lithuania these institutions are developed fairly detailed' (Rozenfelds, 2008).

From the moment the Draft Law was published, the attitude of the civil law experts and the society towards its content, in the opinion of the authors, has been rather sceptical than optimistic. In assessing the public opinion of civil law experts, the authors agree that the development of the Draft Law has objective grounds but it also has significant drawbacks.

Klementijs Rancāns, the board member of the association of apartment owners and tenants 'Ausma' and a lawyer, pointed out in several publications that the Draft Law is legally incorrect, it does not conform to the Constitution and human rights in general, the real value of the land parcel is not determined; and that the problem was created by the state and municipalities, so they must redeem the land, the price of the land under living buildings is abominable, the area of the land parcel attached to the building is determined by default and illegally (Rancāns, 2015).

The solution would be to start with the review of the cadastral value of the land that are under multiapartment residential buildings. The restrictions to the rights of land owners are determined by the Constitution, Article 116. No doubt that the price of the land under multi-apartment residential buildings that are not profitable in Riga or any other place in Latvia must be the same. The price of the land under multi-apartment residential buildings in Vecrīga must be lower than that in city suburbs (Avotiņš, 2016).

Aivars Gontarevs, the Chairman of the Board in a real estate company 'Latio namsaimnieks', discussing the cadastral value comments it: 'Therefore the issue of value must be addressed first, and after that we can deal with the legal aspects of the issue"” (Kḷaviņš, 2016).

Many experts of civil law find the requirement to settle the redemption price in 10 years alarming. Șlahota said that banks will be interested in the financing of the land purchase only to those inhabitants who have the real estate mortgage. It is so because then these properties are united and their value increases. But if there is a forced mortgage, the owner is insolvent and has no financial means to settle the redemption price and if during these 10 years the person does not manage to set the money aside or borrow, there is a possibility that the inhabitant of the apartment may lose the apartment, and this is the biggest risk of this project (Dārziņa, 2016).

Trying to find a fair solution, the law of December 8, 1938, On the Abolition of Divided Real Estate Ownership, which describes quite a simple process of divided real estate property abolition, as well as the Instruction on the Abolition of Divided Real Estate Ownership, which in the opinion of the authors are of great importance in developing the Draft Law, have been analysed. These two documents are the basis for the assessment of the historical order that was applied denoting one-off redemption price and whether it has some influence nowadays.

To obtain a clear vision of how the redemptions rights were put into practice, the authors of the research examined and assessed materials from the State Archives of Latvia, fund No 824 (State Archives of Latvia, 2013), on the redemption procedure in Riga, Kr.Valdemāra iela and Šarlotes iela (group 24, No 8). Having examined the materials, the authors could ascertain that the former owners and their heirs, according to the order defined by the law, received documents with the calculation of 
the redemption price and purchase agreements with the terms of payment (State Archives of Latvia, 2012a). The documents show that irrespective of whether the redemption price was paid or not, the land became the property of these citizens. The one-off payments of the redemption price were examined in the materials of the State Archives of Latvia (2011, 2012a, 2012b, 2001, 2009). But the fact that the redemption price has not been paid was shown by another archive reference (State Archives of Latvia, 2013) and the added documents in which it was stated that 'there is no information in the archive funds about the purchase agreements with Riga City Council till December 15, 1939, and from December 16,1939, till July 21, 1940'.

Despite the fact that authors of the research managed to analyse archive materials only for a small fraction of properties, there is enough material to conclude that there is a multitude of real estate that have not been redeemed according to the law of December 8, 1938, On the Abolition of Divided Real Estate Ownership. Unfortunately, the authors did not manage to find publications that would analyse in detail the issue of the realisation of the above-mentioned norms in Latvia.

Valid conclusions can be found in the judgements of the Supreme Court and the Constitution Court in which the necessity to restore justice and equality and the achievement of legitimate targets, as well as the necessity to ensure conformity of this legislation to the Constitution, solving arguments that have arisen after the Land Reform is stated.

\section{Methodology}

For the study purposes general scientific research methods and specific methods for the interpretation of laws have been used.

General scientific research methods:

Historical analysis - studying the creation and historical development of the divided real estate ownership;

Analytical method - studying laws, case laws, theoretical literature and opinions of different authors, to understand the content of the divided real estate ownership;

Inductive method - studying the problems connected with the laws regulating the divided real estate ownership un coming to general findings of the research;

Deductive method - studying the grounds for the calculation of the redemption price, which can be inferred from the Draft Law and the law of December 8, 1938, On the Abolition of Divided Real Estate Ownership;

Logical construction - for the formulation of findings and suggestions;

Descriptive analysis - analysing in detail the peculiarities of the divided real estate ownership and the method of redemption price calculation, summarising the information and on the basis of acquired findings, providing explanation as well as determining the related problems.

Methods for the interpretation of laws:

Grammatical analysis - to determine precise notion and content of the divided real estate ownership from the linguistic point of view;

Systemic method - interpreting the legal norms related to the termination of the divided real estate ownership and calculating the redemption price, in relation to the Civil Law and other laws;

Teleological method - interpreting the substance of the aim of the divided real estate ownership and methods for redemption price calculation and the laws regulating it;

Historical analysis - explaining the circumstances that served for the development of divided real estate ownership and that created necessity to solve the situation. 


\section{History of divided real estate ownership development}

On 4 May, 1990, the Republic of Latvia restored its independence. Later, on 13 June, 1990, the Supreme Council adopted the decision On Agrarian Reform in the Republic of Latvia, which served as a milestone marking the beginning of the Land Reform, which granted rights of owners in regard to land and buildings (construction), according to the situation on 21 July, 1940, or their heirs. At the same time, any Latvian citizen could acquire land and buildings formerly owned by the state.

At the end of 1989, a group of experts emerged for the preparation of the Agrarian Reform in Latvia, which at its own initiation stated to develop the principles for the reform and defined its objectives. The drafting of the law on the Land Reform and its implementation afterwards was a tough and complicated process, as it had to be carried out in the circumstances of political and ideological instability; there was heated controversy on which political and economic system would be most acceptable for Latvia and about the role of the state and its tasks. Already, in developing the draft of the Land Reform, it appeared that the society lacked common and comprehensive understanding about a fair framework for the reform and its aims and objectives. On the contrary, different, and often conflicting, aims were proposed. The peculiarity of the Land Reform in Latvia is that it was not regulated by a single law or a set of mutually related laws, instead several laws were chaotically developed, and some articles in these laws during the long period until the adoption of the law by the Supreme Council (later in the Saeima) were amended several times, which resulted in contradictions amongst and within these laws (Boruks, 266-268; 2001).

As the researchers of the Land Reform admit, legislation governing the Land Reform was passed hastily, under the influence of different social and political factors; therefore, for several times, it was necessary to make amendments in these laws. The consequences of it can be felt even nowadays.

One of the regulations in which these negative consequences can be observed is the development of divided real estate ownership. Possibly due to haste and ill-considered solutions as well as due to innumerable amendments made during the Land Reform, the principle of physical unity of the property was violated. The Section 968 of the Civil Law stipulates the following: 'A building erected on land and firmly attached to it shall be recognised as a part thereof.' Dealing with cases regarding the restoration of ownership rights to the former owners or their heirs, land ownership rights were restored within the historical boundaries also to the land parcels on which buildings (constructions) owned by other persons were situated. Passing the law On the Time and Procedures for Coming into Force of the Introduction, Inheritance and Property Law Part of the Renewed Civil Law of the Republic of Latvia of 1937, it was defined that 'taking into account the conditions defined in the first part of the Section 14, paragraph 1-4, Sections 968 and 973 cannot be applied, and until the uniting into a single real estate the buildings (constructions) or orchards (trees) shall be considered as independent ownership objects' (Law On the Time and Procedures for Coming into Force of the Introduction, Inheritance and Property Law Part of the Renewed Civil Law of the Republic of Latvia of 1937, 1992).

As written in the annotation of the Draft Law: 'Requiring the restoration of land ownership rights to a definite land parcel within its historical boundaries, the former owner or its heir from the beginning has to take into account that, in case before the restoration of the independence of the Republic of Latvia a building (construction) has been erected on this land parcel that belongs to another person the owner will be obliged to lease the land to the building owners' (Ministry of Justice, 2015). Unfortunately, a more elaborate explanation on the far-reaching consequences and the possible problems was not available. This, however, did not discourage the former owners or their heirs from restoring their ownership rights to such land parcel within their historical borders, even though there were other alternative solutions in the laws of the Land Reform - to require to provide property rights or usage rights to an equivalent land parcel or to require compensation according to the order defined by the law. The authors conclude that under such circumstances, the former owners or their heirs were given a choice but the apartment owners in multi-apartment residential buildings were not offered such a choice and they had to face the facts. This, to some extent, contradicts the Section 1 of the Civil Law, that is, the principle of good faith, according to which '[...] a person may be deprived of 
exercising one's subjective rights or the fulfilment of subjective duties if it is found that the conflicting interests of the other party according to the aim of the law and the circumstances of the case are deemed to be more important' (Senate for the Supreme Court of the Republic, 2005). However, the former owners or their heirs cannot be reproached for ignoring the principle of the good faith, as they exercised their rights provided by the law and possibly did not consider the seriousness of the consequences. Such reproaches can be addressed towards the authors of these Land Reform laws who had ignored the Section 1 of the Civil Law.

Of course, it was possible to solve the restoration of the ownership rights differently, observing the interests of apartment owners in multi-apartment buildings, not restoring the ownership rights to the former owners or their heirs to the land parcels or their parts within the historical boundaries where multi-apartment residential buildings and buildings (constructions) owned by other persons are situated. In Estonia, for example, the former land owners could not restore the property right to a land parcel on which there was situated a building belonging to a third person. Instead, the land owners received a land parcel on which there are no buildings belonging to other persons. But the state maintained the ownership of illegally alienated (nationalised) land on which there were situated buildings belonging to other persons (Ministry of Justice, 2008).

Following the same principle, the ownership was restored to the former owners in Lithuania (with some exceptions). However, no proper attention was paid to it in Latvia; therefore (according to the information of the Ministry of Justice of the Republic of Latvia), '[...] In Latvia, as a result 3677 multi-apartment residential buildings (11 0907 apartments in total), which are situated on 7354 land parcels owned by other persons, have mandatory tenant relationships with the owners of the land parcel' (Ministry of Justice, 2015). Now, in the opinion of authors, there is no point in criticising these decisions, which had and still have negative long-term consequences, but now it is important to adopt effective legal framework that would eliminate the errors of the past and would provide a possibly fair mechanism for the abolition of divided real estate ownership in Latvia.

\section{Redemption price and its calculation, abolishing divided real estate ownership}

As mentioned earlier, there are several deficiencies in the Draft Law. Some of them have been widely discussed amongst the experts of the respective field in press, television, radio and so on. Therefore, the authors will discuss the redemption price and its calculation, as well as the consequences of nonpayment of the redemption price.

According to the Section 1, Paragraph 4 of the Draft Law, the land which is the subject of redemption is 'a land parcel defined according to the legislation regulating the privatisation of residential buildings which is functionally necessary land parcel which coincides with the parcel which is the subject of mandatory divided real estate property ownership' (Ministry of Justice, 2015). The price of the land parcel which is the subject to redemption and the order of its calculation are regulated in Section 5 of the Draft Law and it is quite simple. The price is calculated by multiplying the sum of the cadastral value of the land parcel or its part by the redemption price correction coefficient 1.18 . In the opinion of the authors, the annotation of the Draft Law does not justify why such coefficient has been set and why in such amount. Calculating the redemption price, the cadastral value of the land parcel or land unit valid in respect of the day, when a notice about the exercising the option of redemption is dispatched, is applied (Ministry of Justice, 2015). The makers of the Draft Law find this method of calculation legitimate, reasonable and fair. In the annotation of the Draft Law, it is indicated that the cadastral value comprises $85 \%$ of the real estate's market value. By multiplying the cadastral value with the coefficient 1.18, we obtain a figure that can be comparable to the market value of the real estate (Ministry of Justice, 2015). At the same time, the annotation contains a very important reference to the comments of the European Court of Human Rights, that is, to ensure the social justice, the remuneration for the expropriation of the real estate may be smaller than the market value. However, we may conclude that the lawmakers have disregarded this advice in developing the Draft Law. In Germany, for example, the remuneration is set below the market value. The owners of the buildings purchasing the land under the building must pay only half of the market value; the price may be 
decreased even further if the owner of the building duly informs the land owner about the desire to purchase the land parcel (Ministry of Justice, 2015).

Taking into account the comments of the European Court of Human Rights and the fact that the cadastral value of the real estate is set close to the market value, in calculating the redemption price, only cadastral value or even half of the cadastral value should be taken into account. However, it should be noted that the assessment has been made by taking the existing cadastral value of the real estate into account, as we do not know what may the value be at the moment of the final reading of the Draft Law in Saeima. The authors do not preclude that in case of increase in the cadastral value of the real estate, the number of those apartment owners who will have a desire and an ability to redeem the land may rapidly fall. Therefore, the issue of the method for calculating the cadastral value and the decrease in the cadastral value should be addressed first, because, in the opinion of the authors, cadastral values in some parts of Riga are too high.

It should be stressed that there are land parcels in Latvia that are repurchased from the former owners or their heirs. In such a situation, in calculating the redemption price, the cadastral value or the purchase value should be taken as a basis. The redemption price must be calculated proportionally to the respective redeemable undivided share. If the price of the land purchase is higher than the cadastral value, it must be provided that the redemption price may not be higher than the cadastral value. It must be added that such a requirement is determined by the fact that at the present moment, the cadastral value has almost reached the value of the real estate. Even more, the real estate where there is situated a building belonging to other person is encumbered and its value is lower. Rozenfelds also concluded that ' $[. .$.$] the value of the real estate that is encumbered by forced lease is several times lower than the$ value of the parcel that has no encumbrance' (Constitutional Court, 2011). In the Court's judgment in Case No 2002-12-01 as of 25 March, 2003, it is said: 'Since the consequences of the occupation is a burden that lies on the whole society and it is impossible to remedy these effects completely, the principle of fairness requires that not only the interests of the former land owners or their heirs are taken into account during the Land Reform but also the separate interests of other citizens and the society in general' (Constitutional Court, 2003).

The authors of the study have concluded that unfortunately, in developing the redemption price and the legislation regulating its calculation methods, the historical situation has been taken into account. Until 8 December, 1938, there existed divided real estate ownership between the state or the municipality as with the 'general owner' and natural and legal persons as with 'entitled users with ownership rights'. From the day the law of 8 December, 1938, On the Abolition of Divided Real Estate Ownership came into force, on the basis of Section 1 and 2 of the mentioned law, divided real estate ownership rights defined in agreements or which arise from the laws were revoked and the 'entitled users with ownership rights' were given full ownership rights to the real estate.

However, according to Section 5 of the law of 8 December, 1938, On the Abolition of Divided Real Estate Ownership, entitled users with ownership rights, who were given full ownership rights with this law, had to pay one-off redemption price that was calculated in the order and the amount defined by the law. The norms included in the Sections 3, 5, 6, 7, 8, 10 and 25 determined the term, amount and the order of the payment. Section 25 of the law established that an entitled user with ownership rights can pay the redemption price to the general owner in equal yearly payments during 5 years counting from the day when redemption price has been set. On the basis of Section 35 of the law, the Instruction on the Abolition of Divided Real Estate Ownership, which defined a more detailed regulation of redemption price issues, was issued.

On studying the materials of the National Archives of Latvia (mentioned in the Literature Review), the authors found that many users with ownership rights, who with the law coming into force became the only owners, had paid redemption price, but some had not paid the redemption price. In such circumstances, a situation in which some of the former owners or their heirs are in a more privileged situation in comparison with the other owners who have made the payment has developed. Therefore, in defining the redemption price in the Draft Law, in the opinion of the authors, it is necessary to take these historical facts into account. 
The authors believe that before calculating the redemption price, each owner must be required to submit a certificate from the National Archives of Latvia attesting the fulfilment of the norms of the law of 8 December, 1938, On the Abolition of Divided Real Estate Ownership and the one-off payment for the respective land parcel. In case the payment had not been made, the payable amount must be subtracted from the calculated redemption price. Of course, it would be necessary to decide how to convert the redemption price into the present currency - euro.

In determining the redemption price, it would be necessary to calculate the contributions made, which increased the value of the real estate, and the redemption price must be respectively reduced. It should be pointed out that in many cases, contributions have been made, which considerably increased the value of the land parcels where the ownership rights have been restored to the former owners or their heirs. It can be concluded by examining the documents in the National Archives of Latvia. It may create additional difficulties, but it would ensure justice and equity and would also reduce the burden for the owners of apartments related to the redeeming of the land parcel.

Issues related to the calculation of the cadastral value, conversion of the redemption price, comparing to the amount in euro and the assessment of the contributions can be subject to separate discussion and will not be included in the scope of this research.

One more aspect undermining the completeness of the Draft Law is related to the decision on the order and consequences of redemption rights and redemption price payment.

In the second part of the Section 11 of the Draft Law, it is said: 'Decision on the exercising of redemption option is taken if the co-owners of apartments owning more than a half of apartments in the forced divided real estate have voted in favour of the redemption of the land parcel' (Ministry of Justice, 2015). However, in the third part of Section 11 of the Draft Law, it is said: 'Decision taken in a general meeting of the apartment owners on the exercising of redemption option is binding to all owners of apartments in the building'. Although the Ministry of Justice of the Republic of Latvia in the annotation of the Draft Law has explained the necessity of such regulation, the authors believe that a part of owners, because of insufficient financial means, will not be able to influence the decision, as at the present moment, there is no requirement to obtain a $100 \%$ support of all inhabitants. These apartment owners will then forcefully become the hostage to the situation and as a result may become homeless.

In the first part of the Section 16, it is said: 'If redemption opportunity is used (second part of Section 15 ) in respect to the apartment real estate, where the owner or the owners have not paid their part of the redemption price according to the order defined in this law, a sworn bailiff registers a mortgage in favour of the land parcel owner in the divided real estate as a security for claim in the amount of the respective redemption price' (Ministry of Justice, 2015). Here it must be noted that the 3-month term denoted by the Section 15 of the Draft Law, part 1, is too short. In determining this term, the ability of the apartment owners to make savings in 3 months and also the amount of the minimal wage - EUR 370 - and the average pension must be taken into account. The average pension, for example, in October, 2015, was EUR 292. However, during the past year, the number of people who have received pension under EUR 20 has increased. There is also a growing number of those whose pension is between 20 and 100 Euros (Paparde, 2016). The authors consider that the term must be prolonged from 3 to 6 months and also that the one-year term defined by the Draft Law, Article 7, must be proportionally prolonged.

But in the seventh part of the above-mentioned section, it is said: 'Owner of the mandatory divided real estate land parcel, in whose favour the mortgage is registered, shall not have the right to claim the payment of the unsettled redemption price in 10 years since the registration of the moment of mortgage' (Ministry of Justice, 2015).

This means that after 10 years, the owner of the land parcel will be able to bring claim against the owner of the apartment for the recovery of the debt. It must be pointed out that in developing the Draft Law, the income of the apartment owners, whether there are existing credit agreements and whether all of them will be able to build up savings to settle the redemption payment and at the same time pay 
default interest, determined by the fifth part of the Section 16, have not been assessed. Only general calculations have been made taking as a basis the average wage or pension. However, in the opinion of the authors, it is neither acceptable nor permissible. Therefore, in solving the issue of legal consequences for those apartment owners who will not have settled the redemption payment in due time, a different solution must be sought.

The authors agree with an opinion expressed on the Internet: 'The reform should provide that the land under multi-apartment residential buildings becomes the property of apartment owners or is available to the municipality, from which apartment owners could lease the land under the building for a reasonable price. If an apartment owner is not ready to redeem the land, it should become the property of the state or the municipality and apartment owners could continue to lease the land for a reasonable price' (Association Progresivie Board, 2014). This would be a good solution in situations when the apartment owner is unable to settle the redemption payment even in 10 years. Such apartment owners there will definitely be, because the cadastre value of land parcels in Latvia can considerably vary starting from 1000 EUR to 500000 EUR. The author assumes that those owners of land parcels who will redeem their land with an aim to gain profit from the lease of the land parcel will use their opportunity to alienate the real estate of apartment owner by means of judicial settlement. Unlike in the Land Reform laws of Latvia, in developing the legal framework for the abolition of divided real estate ownership, Estonian lawmakers chose a different solution for situations when illegally alienated land was returned to its former owner or its heirs - to them, land in another place was provided where buildings (constructions) belonging to other persons are not situated. Nationalised land on which buildings (constructions) belonging to other persons were situated remained the state property, thus providing the owners of the buildings (constructions) an opportunity to use it and redeem it (Rancāns, 2016). This principle should also be followed in Latvia in abolishing the divided real estate ownership. The state and municipalities are responsible for the incomplete regulations of the Land Reform. Thus they should assume some part of the responsibility and redeem the land parcels on which multiapartment residential buildings are situated and then they must offer to redeem the land to the apartment owners. Or it must offer long-term lease of the parcel to ensure the rights to property defined by the Section 105 of the Constitution (Constitution of the Republic of Latvia, 1993) also to those persons who would not be able to settle the redemption payment within the statutory deadline. Of course, that would require considerable financial contribution. State Land Service has calculated that the cadastral value of 7,354 land units could be EUR 130,000,000, or even EUR 180,000,000 (Ministry of Justice, 2015). But it must be taken into account that this amount may gradually decrease as the state will receive payment for lease and redemption. Unfortunately, such alternative is not provided by the state, to assume the responsibility and to redeem the land from the owners. Therefore, the authors will offer other solutions in the conclusion of the paper.

\section{Results}

The authors consider that the situation of divided real estate ownership in Latvia has evolved as a result of ill-advised and poorly developed legislation regulating the Land Reform.

The issue of divided real estate ownership has been subject to numerous studies, and in many countries, the legislation regulating divided real estate ownership has already been created. Therefore, several experts have expressed an opinion that it would be necessary to adopt the experience of other countries (e.g. Estonia and Germany). The authors are of the opinion that despite the similarity of the problems, there are several historical, sociological and political factors that are typical only to Latvia. Therefore, it would be quite difficult to adopt the legislation of other countries.

It is important to develop the Draft Law, but there are significant drawbacks in it and its adoption in the present version will not improve the situation and will create even bigger problems, especially to the apartment owners. Therefore, the authors of the Draft Law should consider openly expressed criticism and suggestions for improvement expressed openly in public, and also additional research must be carried out (e.g. about the solvency of apartment owners), and then they must appropriately improve the present version of the Draft Law. 


\section{Conclusions}

1. In restoring the property rights to the former owners or their heirs, the principles of equality and fairness were not followed as on the same grounds the property rights were restored both to those who according to law of December 8, 1938, On the Abolition of Divided Real Estate Ownership had paid the redemption price and to those who had not done it. In developing the Draft Law, these historical circumstances, which are very important in calculating the redemption price, have not been taken into account.

It is necessary to determine precisely in the Draft Law the issue of redemption price calculation taking into account whether the requirements of the law of December 8, 1938, On the Abolition of Divided Real Estate Ownership have been met.

2. The Draft Law should seek an opportunity to reduce the redemption price if the state or municipality has made material contributions in the real estate in order to improve the state of it and to develop it, for example, in the building of land drainage systems, access ways and so on, which has substantially improved the value of the real estate. Therefore, the authors of the Draft Law have to carry out additional research to find out: (1) whether there is real estate in which the state or the municipality has made some contribution since the moment of nationalisation; (2) if there have been such contributions into the real estate, they must be identified; and (3) their amount must be calculated. On the basis of results obtained in such research (providing that the quantity of such real estate where there has been contributions is large), the Regulations of the Cabinet of Ministers that would define the order in which the presence of contributions is denoted and their amount calculated must be developed. Not only lawyers but also the representatives of the respective fields (from the State Land Service, representatives from the Land Register, surveyors, certified real estate agents, experts in construction, etc.) must be invited to participate in the development of these regulations of the Cabinet of Ministers.

3. The Draft Law should seek an opportunity to reduce the redemption price if the owner of the real estate has received lease payment. The amount paid for lease must be deducted from the calculated redemption price.

4. In the Annotation of the Draft, in Section 2.3.1., explanation about the calculation of the redemption price by applying the correction coefficient 1.18 is provided; therefore, redemption price reaches the market value of the real estate. However, the Annotation of the Draft Law does not provide valid explanation why exactly this coefficient has been chosen and why the redemption price is adjusted to the market value. Thus the Section 2.3.1. of the Annotation requires a more detailed explanation.

On the basis of the above, the following amendments should be made in the Draft Law

(a) Change Section 5, part 1, in the following wording:

'(1) The owners of apartments redeem the land paying the redemption price that consists of the sum of the cadastral value of land units or their parts which are included in the land parcel, from this amount a deduction is made in the amount that the owner of the land has received from the apartment owners for the land lease till the day of notification dispatch, mentioned in the Article 6 thereof, plus the sum of contributions made by the state or the municipality in the real estate from the moment of its nationalization till the restoration of the property. The order of calculation of the contribution and the amount is defined by the Cabinet of Ministers.'

(b) Supplement Section 5 and change it to the following wording:

'(5) If land units or their parts included in the land parcel are purchased from the former owners or their heirs on the basis of a purchase agreement, the redemption price shall be set in the amount of the purchase sum registered in the Land Register.'

5. In the Draft Law, Section 15, part 1, a 3-month term is set for the payment of the redemption price. It is too short and not all apartment owners will be able to observe it. Therefore, the term must be prolonged till at least 6 months. The one-year term set in the Subsection 7 of the Draft 
Law should also be respectively prolonged. Thus the following amendments should be done in the Draft Law:

(a) Section 5, Part 1:

replace the word 'three' in the Section 15, Part 1, with 'six'.

(b) Section 7:

replace the word 'year' in the Section 7 with words 'within one year and three months'.

6. Registering a mortgage in favour of the land owner if the apartment owner has not paid the redemption price creates risk to the apartment owner to lose rights of owner to the apartment after 10 years. Such consequences of the divided real estate abolition cannot be justified. Forcing a person to purchase a property not providing a different option after 10 years to ensure the maintaining of the property contradicts the norms of the Constitution, Section 105 and even any moral norms. The authors offer an alternative solution: in cases when the apartment owner is unable to pay the redemption price within 10 years, the respective undivided share in the shared property is taken over by the state, but the apartment owner has the right to long-term lease of the land under the building or until the moment of purchase. The order in which the state takes over the land that has not been redeemed is defined by the Cabinet of Ministers. It must be added that this suggestion is just a concept at the present moment, as the authors see that the state is not interested in the acquisition of the land under multi-apartment residential buildings; therefore, it is too early to offer precise wording to articles of the law.

\section{References}

Avotiňš, V. (2016). K Rancāns: maksājam kā vergi [Accessed 08.08.2016]. Available from Internet: http://nra.lv/latvija/167959-irnieku-aizstavis-klementijs-rancans-maksajam-ka-vergi.htm

Biedrība PROGRESİVIE valde [Board of the Association Progressive] (2014). Piespiedu nomas problèma jāatrisina! [Accessed 20.03.2016] Available from Internet: http://www.progresivie.lv/2014/05/15/piespieduzemes-nomas-problema-jalikvide-tas-sakne/

Boruks, A. (2001). Zemes izmantošana un kadastrs Latvijā. Rīga, Latvijas lauksaimniecības universitātes Skrīveru zinātnes centrs, Latvijas Valsts zemes dienests, 266-268.

Civil Law of Latvia (1937). [Accessed 01.08.2016.] Translation by Translation and Terminology Centre, 2001. Available from Internet: http://www.vvc.gov.lv/advantagecms/LV/tulkojumi/index.html

Constitution of the Republic of Latvia (1922). [Accessed 01.08.2016.] Consolidated by Valsts Valodas centrs. Available from Internet: http://www.vvc.gov.lv/advantagecms/LV/tulkojumi/index.html

Constitutional Court (2011). 27.01.2011. Judgement in Case No 2010-22-01[Accessed 08.08.2016]. Available from Internet: http://www.satv.tiesa.gov.lv/wp-content/uploads/2016/02/2010-22-01_Spriedums.pdf

Constitutional Court (2003). 25.03.2003. judgement in Case 2002-12-01. [Accessed 08.08.2016]. Available from Internet: http://likumi.lv/doc.php?id=73143

Dārziṇa, L (2016). Piespiedu nomas izbeigšanas likumprojekti joprojām Saeimas komisijā [Accessed 08.08.2016]. Available from Internet: http://www.lvportals.lv/print.php?id=276886

Kḷaviṇš, A. (2016). "Latio namsaimnieks": Dalītā īpašuma jautājumā vispirms jānosaka objektīva zemes gabala vèrtība [Accessed 01.08.2016]. Available from Internet: http://www.lanida.lv/index.php?option=com k2\&view=item\&id=6685:latio-namsaimnieks-dalita-ipasumajautajuma-vispirms-janosaka-objektiva-zemes-gabala-vertiba\&lang $=$ lv

Law On the Time and Procedures for Coming into Force of the Introduction, Inheritance and Property Law Part of the Renewed Civil Law of the Republic of Latvia of 1937, (1992). Zinotājs (29), 30.07.1992.

Law On the Abolition of the Divided Real Estate Ownership (1938). Valdības Vēstnesis (286), 16.12.1938.

Ministry of Justice of the Republic of Latvia (2008). Civillikuma zemes un èku (būvju) nedalämības koncepta pilnĭgas ieviešanas problēma. [Accessed 08.08.2016]. Available from Internet: 
file://D:/Downloads/lv_documents_petijumi_final_report.re_land_reform_and_divided_property_concept.2008 12_12.lat.janisl\%20(3).pdf

Ministry of Justice (1938). Instruction on the Abolition of Divided Real Estate Ownership. Valdības Vēstnesis (23), 26.01.1939.

Ministry of Justice (2015). Draft Law On the Abolition of Forced Divided Real Estate Ownership in Privatised Multi-Apartment Buildings [Accessed 29.03.2016]. Available from Internet: http://titania.saeima.lv/LIVS12/saeimalivs12.nsf/0/CD1 A6440A69EB8BAC2257ED1003CBA2C?OpenDocume $\mathrm{nt}$

National Archives of Latvia (2001). 15.03.2001. Reference No 5-U-738 - not published

National Archives of Latvia (2009). 16.01.2009. Reference No 5-U-7752/1 - not published

National Archives of Latvia (2011). 21.10.2011. Reference No 5-U-3437/1 - not published

National Archives of Latvia (2012)a. 24.02.2012 Reference No 5-U-395 - not published

National Archives of Latvia (2012)b. 22.03.2012. Reference No 5-U-741 - not published

National Archives of Latvia (2013). 15.10.2013. Reference No 5-U-3172/2 - not published

State Land Service (2015). Nekustamā īpašuma tirgus pārskats. Dalītais īpašums un piespiedu noma daudzdzīvokḷu mājās Latvijā. [Accessed 08.08.2016]. Available from Internet: http://vzd.gov.lv/files/parskats_15052015_gala.pdf

Supreme Court of the Republic of Latvia (2005). 09.02.2005. Judgement of the Supreme Court of the Republic of Latvia Senate in Case No SKC - 75 [Accessed 29.03.2016.]. Available from Internet: http://at.gov.lv/files/uploads/files/archive/department1/2005/skc-75-05.pdf

Supreme Court of the Republic of Latvia (2015). 19.11.2015. Judgement of the Chamber of Civil Cases of the Supreme Court in Case No C04212600, not published.

Paparde, I. (2016). Vidējā pensija aug, taču vairāk arī trūcìgu pensionāru [Acessed 08.08.2016]. Available from Internet: http://nra.lv/latvija/161630-videja-pensija-aug-tacu-vairak-ari-trucigu-pensionaru.htm

Rancāns, K. (2015). Dalītā ìpašuma izbeigšanas likumprojekts - būtībā nostiprināt piespiedu nomas attiecības un turpmāk atsavināt visus dzīvoklus [Accessed 08.08.2016]. Available from Internet: http://www.pietiek.com/raksti/dalita_ipasuma_izbeigsanas_likumprojekts_butiba_nostiprinat_piespiedu_nomas - attiecibas

Rancāns, K. (2013). Zemes zem daudzdzìvokḷ mājām kadastrālā vērtēsana kā Latvijas valsts varas likumdošanas fikcija. [Accessed 20.03.2016] Available from Internet: https://manabalss.lv/system/initiatives/documents/000/000/604/original/13896892051UQMTI.pdf?1415878621

Rozenfelds, J. (2013). Zemes piespiedu nomas institūta izveidošana, zemes zem daudzdzīvoklu mājām kadastrālā vērtēšana un Civillikuma 968.panta izñēmumi kā Latvijas valsts varas likumdošanas fikcija [Accessed 08.08.2016]. Available from Internet: http://www.ir.lv:889/blogi/ekonomika/zemes-piespiedu-nomas-institutaizveidosana-zemes-zem-daudzdzivoklu-majam-kadastrala-vertesana-un-civillikuma-968-panta-iznemumi-kalatvijas-valsts-varas-likumdosanas-fikcija

Rozenfelds, J. (2008). PĒTIIJUMS par Civillikuma Lietu tiesību dalas (ceturtās, piektās, sestās un septītās nodalas) modernizācijas nepieciešamību [Accessed 29.03.2016]. Available from Internet: http://at.gov.lv/lv/resursi/petijumi/ 